\title{
ANALISIS INCREMENTAL COST DALAM PENGAMBILAN KEPUTUSAN PESANAN PADA UD. SINAR ABADI SINGARAJA TAHUN 2014
}

\author{
Putu Teti Insani Tanaya \\ Jurusan Pendidikan Ekonomi, Fakultas Ekonomi dan Bisnis \\ Universitas Pendidikan Ganesha \\ Singaraja, Indonesia \\ e-mail : tetiinsanitanaya@yahoo.com
}

\begin{abstract}
ABSTRAK
Penelitian ini bertujuan untuk mengetahui (1) pemisahan biaya semi variabel menjadi biaya variabel dan biaya tetap untuk penentuan contribution margin dalam pengambilan keputusan pesanan pada UD.Sinar Abadi Singaraja tahun 2014 dan (2) penerapan incremental cost dalam pengambilan keputusan pesanan pada UD.Sinar Abadi Singaraja tahun 2014. Penelitian ini merupakan penelitian deskriptif dengan pendekatan kuantitatif. Subjek penelitian ini adalah UD.Sinar Abadi Singaraja dan objek penelitian ini adalah incremental cost dalam pengambilan keputusan pesanan. Data dikumpulkan dengan metode dokumentasi yang selanjutnya dianalisis dengan metode regresi kuadrat terkecil dan analisis incremental cost. Hasil penelitian menunjukkan bahwa (1) pemisahan biaya semi variabel sebesar Rp. 14.068.700,00 dipisahkan menjadi biaya variabel Rp. 6.826.660,00 dan biaya tetap sebesar Rp.7.242.039,08. (2) penerapan incremental cost menunjukkan bahwa dengan mengeluarkan biaya tambahan sebesar Rp.1.230.234,00 mampu menutup biaya variabel sebesar Rp. 19.404.500,00 dan memberikan tambahan laba bagi perusahaan sebesar Rp.16.865.266,00, sehingga pesanan khusus yang ditawarkan dapat diterima.
\end{abstract}

Kata Kunci: incremental cost, pengambilan keputusan, batas kontribusi.

\begin{abstract}
This research aims to determine (1) the separation of semi-variable cost into variable cost and fixed cost for the determination of contribution margin in decision making orders at UD.Sinar Abadi Singaraja 2014 and (2) the application of the incremental cost in the order of decision making at UD.Sinar Abadi Singaraja 2014. This study used descriptive with quantitative approach. The subjects research is UD.Sinar Abadi Singaraja, and the object research is the incremental cost in the order of decision making. Data collected by the method of documentation and were analyzed by method of least square regression and analysis of the incremental cost. The results showed is (1) that semi-variable cost Rp. 14.068.700,00 divided into variable cost Rp. 6.826.660.92 and fixed cost Rp. 7.242.039,08, (2) the application of the incremental cost the results showed is with the incremental cost Rp.1.230.234,00 were able to close the variable cost Rp. $19.404 .500,00$, and provide additional income for the company Rp.16.865.266,00, therefore it is still possible for the company to receive another special orders.
\end{abstract}

Keyword: incremental cost, making decision, contribution margin.

\section{PENDAHULUAN}

Sejalan dengan turunnya laju pertumbuhan sektor industri, persaingan antar industri sejenis pun sangat kompetitif. Sehubungan dengan keadaan ini, manajemen mempunyai peran yang amat penting dalam pencapaian tujuan perusahaan, yaitu untuk mempertahankan kelangsungan hidup perusahaan dengan pengoptimalan sumber daya yang dimiliki seperti mesin, material, modal dan manusia secara efektif dan efisien. Berhasil tidaknya suatu perusahaan ditandai dengan kemampuan manajemen dalam melihat kesempatan pada masa yang akan datang baik jangka panjang maupun jangka pendek. Pengambilan keputusan dapat digolongkan menjadi dua yaitu keputusan yang berhubungan dengan 
perencanaan jangka pendek dan keputusan yang berhubungan dengan perencanaan jangka panjang. Ukuran yang sering dipakai untuk menilai berhasil atau tidaknya manajemen perusahaan adalah laba yang dihasilkan dari operasional perusahaan.

Menurut Sugiri,Selamet(2009:101) pengambilan keputusan adalah memilih salah satu di antara berbagai alternatif tindakan yang ada. Pemilihan ini biasanya menggunakan dasar ukuran tertentu, apakah profitabilitas atau penghematan biaya. Semakin tinggi kualitas informasi, maka diharapkan semakin tinggi kualitas keputusan yang diambil. Salah satu jenis informasi yang dibutuhkan oleh manajemen sebagai dasar perencanaan dan pengambilan keputusan adalah informasi akuntansi diferensial (differential accounting information). Manajemen membutuhkan informasi akuntansi diferensial ini untuk memilih alternatif tindakan yang terbaik, di antara alternatif yang tersedia. Menurut Mulyadi(2009:125) Informasi akuntansi diferensial adalah suatu informasi yang menyajikan perbedaan aktiva, pendapatan, dan biaya dalam alternatif tindakan tertentu dibandingkan dengan alternatif tindakan lain. Pada informasi diferensial umumnya manajemen mengahadapi empat macam pengambilan keputusan dalam jangka pendek, yaitu (1) membeli atau membuat sendiri, (2) menjual atau memproses lebih lanjut suatu produk, (3) menghentikan atau melanjutkan produksi produk tertentu, dan (4) menerima atau menolak pesanan khusus.

Menurut Sugiri,Selamet(2009:115) membuat keputusan adalah salah satu fungsi pokok manajer. Dalam perusahaan manajer selalu dihadapkan pada masalah untuk membuat keputusan produk apa yang akan dijual, metode produksi apa yang akan digunakan, berapakah harga jual produk perusahaan, saluran distribusi apa yang digunakan, apakah akan menerima pesanan khusus dengan harga khusus pula, dan sebagainya. Pembuatan keputusan biasanya menjadi tugas yang sulit karena adanya berbagai permasalahan yang kompleks dengan berbagai alternatif yang tersedia.

Seringkali perusahaan menerima permintaan dari konsumen untuk memproduksi produk di bawah harga jual normal perusahaan, maka adakalanya perusahan perlu melakukan pemisahan biaya semi variabel menjadi biaya variabel dan biaya tetap untuk mengetahui apakah nantinya akan menimbulkan pertambahan marjin kontribusi yang diterima perusahaan. Ahmad,Dunia

(2012:161) mengemukakan pengertian contribution margin adalah perbedaan antara harga jual per unit dan harga variabel per unit. Contribution margin juga dapat pula dinyatakan sebagai suatu persentase dari pendapatan penjualan. Cara penentuan contribution margin dapat dilakukan dengan melihat selisih antara harga jual dan harga variabel yang ditetapkan perusahaan. Pesanan khusus dapat diterima apabila memberikan contribution margin positif bagi perusahaan. Selama harga jual masih dapat menutup biaya variabel maka menerima pesanan khusus merupakan keputusan yang tepat.

Analisis diferensial adalah sebuah model keputusan yang dapat digunakan untuk mengevaluasi perbedaanperbedaan dalam pendapatan dan biaya yang berkaitan dengan berbagai alternatif tindakan. Biaya yang dipertimbangkan dalam analisis diferensial bukannya biaya yang digunakan di dalam laporan keuangan konvensional. Untuk tujuan pengambilan keputusan, klasifikasi biaya meliputi. (1) Relevant cost biaya yang akan terjadi di masa yang akan datang dan berbeda di antara alternatif yang sedang dipertimbangkan di dalam suatu keputusan. (2) Differential cost adalah perbedaan biaya relevan antara dua alternatif atau lebih. (3) Unavoidable cost biaya yang tidak akan berbeda di antara berbagai alternatif keputusan, apakah biaya itu akan terjadi di masa mendatang atau telah terjadi di masa lalu. (4) Opportunity cost 
manfaat yang dikorbankan karena menolak suatu alternatif, sementara menerima alternatif lain. (5) Variable Costing dimana metode ini menyajikan data yang bermanfaat untuk pembuatan keputusan jangka pendek.

Incremental cost adalah tambahan biaya yang terjadi jika suatu alternatif yang berkaitan dengan perubahan volume kegiatan pilihan. Biaya tambahan merupakan informasi akuntansi manajemen dalam pengambilan keputusan yang berhubungan dengan penambahan dan pengurangan volume kegiatan. (7) Biaya Depresiasi merupakan alokasi secara periodik harga pokok aktiva tetap yang diperoleh padawaktu lampau. Depresiasi adalah berasal dari keputusan penanaman modal jangka panjang.

Suatu perusahaan terutama perusahaan industri selain menghasilkan dan menjual produknya secara langsung, kadangkala berada dalam posisi untuk menerima atau menolak suatu pesanan khusus atau produksinya. Menurut Ahmad Kamarudin(2007:132) adapun syaratsyarat yang perlu diperhatikan dalam mempertimbangkan penerimaan pesanan khusus sebagai berikut (1) pertambahan biaya tidak melebihi pertambahan penghasilan dari pesanan khusus tersebut, (2) kapasitas baik produksinya maupun penjualan perusahaan masih ada yang menganggur karena apabila melampui kapasitas penuh akan berakibat jumlah biaya tetap akan berubah. Menurut Mulyadi(2009:210) kapasitas adalah volume atau jumlah produk yang dapat dihasilkan oleh perusahaan dalam periode tertentu. Kapasitas menganggur yaitu kapasitas atau volume yang tidak dipergunakan untuk produksi. Dalam penentuan harga pokok produk semua biaya produksi dibebankan sepenuhnya baik biaya variabel maupun biaya tetap, namun khusus dalam pengambilan keputusan jangka pendek digunakan biaya variabel karena dari pesanan tersebut mungkin saja dapat meningkatkan laba secara keseluruhan selain memanfaatkan kapasitas yang menganggur. Pesanan ini dapat menutup kelebihan biaya overhead pabrik tetap dihitung sebesar kapasitas penuh. Pesanan khusus yang dimaksud dalam tulisan ini adalah pesanan di luar pesanan biasa dengan harga jual minimal yang telah ditetapkan perusahaan. Pesanan khusus dapat diterima apabila ada kapasitas produksi perusahaan yang menganggur, di samping itu tidak akan mempengaruhi harga jual yang biasanya lebih tinggi menjadi ikut turun dengan pertimbangan bahwa tambahan biaya yang dikeluarkan untuk produksi pesanan khusus tersebut sesuai dengan pendapatan yang diperoleh perusahaan. Menurut Adolph Matz,dkk (2000:45) hal pokok yang perlu dilakukan oleh manajer adalah tidak langsung menolak pesanan khusus tersebut hanya karena harga beli yang ditawarkan oleh pihak pembeli lebih rendah daripada harga jual normal yang diberlakukan oleh perusahaan. Manajer perlu mengevaluasi tawaran pesanan khusus secara lebih mendalam. Pesanan khusus adalah pesanan di luar dari produksi yang biasa perusahaan produksi dan harganya lebih murah daripada harga jualnya. Pesanan khusus yang dimaksud dalam tulisan ini adalah pesanan di luar pesanan biasa dengan harga jual minimal yang telah ditetapkan perusahaan. Pesanan khusus dapat diterima apabila ada kapasitas produksi perusahaan yang menganggur, di samping itu tidak akan mempengaruhi harga jual yang biasanya lebih tinggi menjadi ikut turun dengan pertimbangan bahwa tambahan biaya yang dikeluarkan untuk produksi pesanan khusus tersebut sesuai dengan pendapatan yang diperoleh perusahaan.

Menurut Sugiri,Selamet (2009: 242) umumnya perusahaan mempunyai kapasitas menganggur yang seringkali mendorong manajemen untuk mempertimbangkan penetapan harga jual di bawah harga jual yang diterapkan pada pesanan khusus atau tertentu. Dalam pengambilan keputusan 
menerima atau menolak pesanan khusus, informasi akuntansi yang relevan adalah pendapatan diferensial dan biaya diferensial. Dalam menerima ataupun menolak sebuah pesanan dari para pelanggan diperlukan adanya sebuah penghitungan yang cermat. Hal itu berfungsi untuk menghindari kerugian perusahaan. Salah satu cara untuk memutuskan menerima atau menolak pesanan yaitu dengan menggunakan informasi akuntansi diferensial. Tetapi dalam hal ini, informasi akuntansi diferensial yang digunakan adalah pendapatan diferensial dengan biaya diferensial.

Harga pokok variabel dapat pula dipakai oleh manajemen dalam menentukan harga jual minimal atas pesanan khusus (special order) sehubungan dengan keputusan untuk menerima atau menolak pesanan khusus yang harga jualnya di bawah harga jual normal perusahaan. Analisis incremental cost akan dapat dilaksanakan bila perusahaan menggunakan metode variabel costing dalam penentuan harga pokok produksinya, karena setiap perusahaan yang berhubungan dengan volume kegiatan akan dapat dikendalikan manajemen, apabila unsur biaya terbagi atas unsur tetap dan variabel dimana pada umumnya biaya relevan yang terpengaruh oleh suatu keputusan yang diambil khususnya berhubungan dengan perubahan volume kegiatan adalah biaya variabel.

Menurut Sugiri,Selamet (2009: 200) Alat analisis untuk pengambilan keputusan jangka pendek dalam menganalisis pesanan - pesanan khusus di bawah harga jual normal yang digunakan adalah metode variabel costing yaitu dengan membandingkan harga pesanan khusus dengan harga pokok variabel suatu produk. Apabila dalam perbandingan tersebut harga pesanan khusus lebih besar dibandingkan harga pokok variabel suatu produk maka pesanan khusus tersebut dapat diterima, sedangkan bila harga pesanan khusus lebih kecil dibandingkan dengan harga pokok variabel maka pesanan khusus dapat ditolak. Kriteria tersebut akan dapat dipenuhi bila didasari atas asumsi bahwa tambahan pesanan tidak melebihi kapasitas normal sehingga biaya tetap yang dibebankan tidak berubah. Besarnya kenaikan laba dari pesanan khusus adalah sebesar batas kontribusi dari pesanan khusus yang bersangkutan. Menurut Ahmad,Kamarudin (2007:112) dalam menerima atau menolak pesanan, hendaknya tidak semua pesanan yang datang dapat secara langsung diterima. Ada kriteria khusus yang harus diperhatikan, yaitu perkiraan pendapatan yang akan diterima oleh perusahaan. Apabila pesanan ini menguntungkan bagi perusahaan, maka pesanan dapat langsung diterima, tetapi pesanan akan memberikan sedikit penghasilan bahkan rugi sebaiknya pesanan tidak diterima, karena perusahaan harus mengestimasikan konsekuensi dari pesanan tersebut. Berdasarkan manfaat akuntansi diferensial maka pembahasan di sini hanya memfokuskan pada satu bagian, yaitu membeli atau membuat sendiri (make or buy decision). Tujuan akuntansi biaya mencakup perencanaan dan pengendalian biaya, penentuan harga pokok produk atau jasa yang dihasilkan perusahaan dengan tepat dan teliti berdasarkan pencatatan, pengambilan keputusan oleh manajemen. Kegunaan variable costing method harus juga dilihat dari tujuan akuntansi biaya itu sendiri, oleh karenanya dengan menyajikan informasi biaya harus sesuai dengan tingkah lakunya dan dalam hubungannya dengan perubahan kegiatan perusahaan,

UD.Sinar Abadi memiliki 62 pelanggan tetap terdiri dari beberapa toko kue ataupun perseorangan baik berada di Singaraja ataupun di luar Singaraja. Dalam memenuhi pesanan relugar, perusahaan menetapkan harga jual normal yaitu Rp.4.500/kotak yang di dalam 1 kotak terdiri dari 10 potong kue pia. Selain melayani pesanan dari 
pelanggan tetap, perusahaan sewaktuwaktu juga menerima pesanan khusus di luar pesanan relugar dari pelanggan tetap. Dalam setiap bulannya perusahaan menerima pesanan khusus dari berbagai pelanggannya dengan menawarkan harga untuk pesanan khususnya beraneka ragam pula. Dari keseluruhan pesanan khusus kerugian total perusahaan sebesar Rp. 7.527.000,00 per satu periode. Dari permasalahan tersebut dipandang perlu perusahaan menerapkan konsep incremental cost sebagai alternatif pengambilan keputusan karena perusahaan dalam pengambilan keputusan pesanan masih menggunakan perhitungan manual hanya dengan membandingkan harga jual normal produk dengan harga pesanan khusus untuk mengetahui kerugian per unit dan mengalikan antara jumlah pesanan khusus yang diterima dengan kerugian per unit untuk mengetahui jumlah total kerugian, hal tersebut disebabkan karena kurangnya pengetahuan manajemen mengenai alternatif-alternatif yang dapat digunakan dalam pengambilan keputusan pesanan. Dari permasalahan menganjurkan perusahaan untuk menggunakan analisis incremental cost karena dapat digunakan sebagai dasar pengambilan keputusan pesanan bagi perusahaan, dengan analisis ini memungkinkan perusahaan untuk memperoleh tambahan laba. Menurut Mulyadi (2009:121) definisi biaya tambahan (incremental cost) adalah tambahan biaya yang terjadi jika suatu alternatif yang berkaitan dengan perubahan volume kegiatan pilihan. Biaya tambahan merupakan informasi akuntansi manajemen dalam pengambilan keputusan yang berhubungan dengan penambahan dan pengurangan volume kegiatan. Supriyono (2005:400) menyatakan incremental cost adalah biaya yang akan ditambahkan atau biaya yang tidak akan dikorbankan apabila suatu alternatif tertentu tidak dipilih untuk dilaksanakan. Biaya tambahan merupakan jumlah semua biaya relevan yang berhubungan dengan suatu alternatif tindakan yang kemungkinan akan dilaksanakan atau mungkin juga tidak dilaksanakan oleh manajemen maka biaya tambahan mungkin dapat terjadi mungkin juga tidak, jika alternatif diusulkan bukan merupakan penambahan kegiatan melainkan merupakan peniadaan suatu kegiatan yang sekarang ada, maka biaya tertentu yang ada sekarang dapat dihindari biaya ini disebut biaya terhindarkan (avoidable cost) yaitu biaya yang tidak akan terjadi jika suatu alternatif dipilih. Sesungguhnya biaya terhindarkan merupakan variasi dari biaya tambahan, oleh karena itu sering disebut sebagai sebagai penghematan biaya tambahan (incremental saving). Pengertian biaya tambahan dan biaya terhindari sangat penting artinya dalam pengambilan keputusan karena biaya tersebut berpengaruh jika suatu alternatif dipilih.

Analisis incremental cost ini memungkinkan perusahaan untuk menerima pesanan khusus dengan pertimbangan sama yaitu untuk memperoleh tambahan laba. Perusahaan kadangkala harus memutuskan apakah akan menerima pesanan khusus (special order) atau akan menolaknya, pesanan khusus biasanya harganya lebih murah dari pada harga jual normal. Apabila perusahaan ingin tetap untung, kebijakan penentuan harga jangka panjangnya seharusnya seimbang pada semua biaya yang dikeluarkan. Walaupun demikian, manakala terdapat kapasitas menganggur pesanan khusus mungkin merupakan keputusan yang tepat untuk diterima walaupun harganya lebih rendah daripada harga jual normal.

Adapun penelitian ini bertujuan untuk mengetahui (1)pemisahan biaya semi variabel ke dalam komponen biaya tetap dan biaya variabel dalam penentuan contribution margin pesanan pada UD. Sinar Abadi Singaraja tahun 2014 dan (2) penerapan analisis incremental cost dalam pengambilan keputusan pada UD.Sinar Abadi Singaraja tahun 2014. Hal ini yang 
melatar belakangi penelitian "Analisis incremental cost dalam pengambilan keputusan pesanan pada UD. Sinar Abadi Singaraja tahun 2014".

\section{METODE}

Penelitian ini merupakan penelitian deskriptif dengan pendekatan kuantitatif yang bertujuan untuk menggambarkan keadaan atau suatu fenomena yang terjadi di suatu perusahaan. Data yang diperlukan dalam penelitian ini berupa jumlah produksi, kapasitas produksi, jumlah penjualan, harga jual produk, anggaran bahan baku langsung, biaya tenaga kerja langsung, biaya resparasi pemeliharaan aktiva tetap dalam proses produksi, kalkulasi biaya produksi periode 2014. Dengan adanya penelitian ini diharapkan mampu memberikan sumbangan pemikiran kepada pihak manajemen di UD.Sinar Abadi mengenai menerima atau menolak pesanan khusus. Subjek dalam penelitian ini adalah UD.Sinar Abadi dan objek penelitian ini adalah penerapan incremental cost dalam pengambilan keputusan pesanan. Metode analisis data yang digunakan dalam penelitian ini adalah untuk memisahkan biaya semi variabel ke dalam elemen biaya tetap dan biaya variabel metode regresi kuadrat terkecil (Least Square regression Method) dengan rumus $Y=a+b(X)$, dan untuk analisis pemilihan alternatif incremental cost dengan pesanan khusus dan tanpa pesanan khusus, dimana variabel yang digunakan adalah contribution margin, dengan rumus yang tampak pada Tabel.1 (Sugiri,Selamet, 2009:106).

Tabel 1. Perhitungan penerapan incremental cost dalam pengambilan keputusan pesanan

\begin{tabular}{lccc}
\hline \multicolumn{1}{c}{ Keterangan } & Penjualan Tanpa & Penjualan Pesanan Khusus & Total \\
& Pesanan Khusus & XXX & XXX \\
\hline Produksi & XXX & XXX & XXX \\
Penjualan & $(X X X)$ & $(X X X)$ & $(X X X)$ \\
Total Biaya Variabel & $X X X$ & $X X X$ & $X X X$ \\
Batas Kontribusi & $(X X X)$ & - & $(X X X)$ \\
Total Biaya Tetap & - & $(X X X)$ & XXX \\
Biaya Tambahan & $X X X$ & $X X X$ & \\
Laba/Rugi & & & \\
& & & \\
\hline
\end{tabular}

\section{HASIL DANPEMBAHASAN \\ Hasil Penelitian}

Besarnya biaya bahan baku yang dikeluarkan oleh perusahaan dalam memproduksi kue pia selama tahun 2014 untuk 610.068 kotak kue pia dijabarkan sebagai berikut. Untuk memproduksi 1 kotak kue pia menurut bagian produksi pada perusahaan UD.Sinar Abadi, maka dibutuhkan kacang ijo sebanyak $0,08 \mathrm{~kg}$, sehingga dalam memproduksi kue pia sebanyak 610.068 kotak maka dibutuhkan kacang ijo $48.805,44 \mathrm{~kg}(0,08 \mathrm{~kg} \times 610.068$ kotak). Maka besarnya pembelian kacang ijo adalah Rp.366.040.800,00 $(48.805,44 \times \operatorname{Rp} 7.500,00$ ). Dalam melakukan prouksi kue pia perusahaan
UD. Sinar Abadi, maka dibutuhkan gula pasir sebanyak $0,05 \mathrm{~kg}$ untuk 1 kotak kue pia, sehingga untuk memproduksi kue pia sebanyak 610.068 kotak dibutuhkan gula pasir sebanyak $30.503,40 \mathrm{~kg}$ ( $610.068 \times 0,05 \mathrm{~kg})$. Dengan demikian maka besarnya pembelian gula pasir sebesar Rp. 224.027,200,00 (30.503,40 $x$ Rp.8.000,00). Untuk memproduksi 1 kotak kue pia menurut bagian produksi UD. Sinar Abadi, maka dibutuhkan garam sebesar $0,010 \mathrm{~kg}$ sehingga dalam memproduksi kue pia 610.068 kotak maka dibutuhkan garam sebesar $6.100,68 \mathrm{~kg}$. Dengan demikian maka besarnya pemakaian garam adalah $\mathrm{Rp}$. $3.050 .340,00 \quad(6.100,68 \mathrm{~kg} \quad x \quad \mathrm{Rp}$ 
500,00). Untuk memproduksi 1 kotak kue pia menurut bagian produksi UD.Sinar Abadi maka membutuhkan tepung terigu sebesar $0,025 \mathrm{~kg}$, sehingga dalam memproduksi kue pia 610.068 maka dibutuhkan tepung terigu sebesar 15.251,70 kg. Hal ini berarti bahwa besarnya pembelian tepung terigu sebesar Rp. $\quad 68.632 .650$ $(15.251,70 \mathrm{~kg} \times \mathrm{Rp} 4.500,00)$.

Kemudian besarnya biaya tenaga kerja langsung dalam proses produksi kue pia selama tahun 2014 untuk memproduksi 610.068 kotak kue pia dapat diuraikan sebagai berikut. Adapun jumlah jam kerja dalam pencampuran bahan baku dalam memproduksi satu kotak kue pia menurut perusahaan selama 7 jam, sehingga dalam satu tahun melakukan pencampuran bahan baku sebesar 2.100 jam ( 7 jamx25 harix12 bulan) dengan tenaga kerja sebanyak 7 orang selanjutnya biaya tenaga kerja langsung Rp.51.450.000,00 ( 2100 jam x 7 orang
X Rp 3.500,00). Adapun jumlah jam kerja dalam memproduksi satu kotak kue pia menurut perusahaan selama 7 jam, sehingga dalam melakukan pengolahan bahan baku sebesar 610.068 kotak dibutuhkan jam tenaga kerja langsung 7 jam dan setahun 2.100 jam dengan jumlah tenaga kerja sebanyak 8 orang. Selanjutnya biaya tenaga kerja langsung Rp $63.000 .000,00$ (2.100 jam $x 8$ orang $x$ $3.750,00)$. Adapun besarnya jumlah jam kerja yang dikeluarkan oleh perusahaan dalam pengemasan barang jadi sebesar 7 jam atau pertahun 2.100 jam. Selanjutnya biaya tenaga kerja langsung yang dikeluarkan oleh perusahaan adalah sebesar $\mathrm{Rp}$ $34.125 .000,00$ ( 2.100 jam $\times 5$ orang $x$ Rp. 3.250,00).

Selanjutnya untuk mengetahui pemisahan biaya semivariabel menjadi biaya variabel dan biaya tetap dapat dilihat pada Tabel 2.

Tabel 2. Regresi Volume Produksi dengan Biaya Reparasi dan Pemeliharaan Aktiva Tetap Bulan Januari s/d Desember Tahun 2014

\begin{tabular}{lcccc}
\hline Bulan & $\begin{array}{c}\text { Volume Produksi } \\
(\mathrm{X})\end{array}$ & $\begin{array}{c}\text { Biaya } \\
\text { Pemeliharaan } \\
(\mathrm{Y})\end{array}$ & $\mathrm{X}^{2}$ & $\mathrm{XY}$ \\
\hline Januari & 50.313 & 1.250 .000 & 2.531 .397 .969 & 62.891 .250 .000 \\
Februari & 50.919 & 1.150 .000 & 2.592 .744 .561 & 58.556 .850 .000 \\
Maret & 50.608 & 1.246 .500 & 2.561 .169 .664 & 63.082 .872 .000 \\
April & 50.312 & 1.278 .350 & 2.531 .297 .344 & 64.316 .345 .200 \\
Mei & 52.114 & 1.162 .350 & 2.715 .868 .996 & 60.574 .707 .900 \\
Juni & 54.210 & 1.216 .500 & 2.938 .724 .100 & 65.946 .465 .000 \\
Juli & 50.312 & 1.150 .000 & 2.531 .297 .344 & 57.858 .800 .000 \\
Agustus & 50.215 & 1.100 .000 & 2.521 .546 .225 & 55.236 .500 .000 \\
September & 50.919 & 1.065 .000 & 2.592 .744 .561 & 54.228 .735 .000 \\
Oktober & 50.218 & 1.100 .000 & 2.521 .847 .524 & 55.239 .800 .000 \\
November & 50.310 & 1.150 .000 & 2.532 .001 .761 & 57.856 .500 .000 \\
Desember & 50.218 & 1.200 .000 & 2.521 .847 .524 & 60.261 .600 .000 \\
\hline Jumlah & 610.068 & 14.068 .700 & 31.030 .839 .112 & 715.413 .126 .100 \\
\hline
\end{tabular}

Berdasarkan Tabel 2 mengenai hasil regresi antara volume produksi dengan biaya reparasi dan pemeliharaan aktiva tetap dari bulan Januari s/d bulan Desember tahun 2014 maka selanjutnya besarnya biaya variabel dan biaya tetap perkotak dapat ditentukan melalui rumus sebagai berikut.

$b=\frac{n \sum X Y-\left(\sum X\right)\left(\sum Y\right)}{n \sum X^{2}-\left(\sum X\right)^{2}}$ 
$b=\frac{12(715.413 .126 .100)-(610.068)(14.068 .700)}{12(31.030 .839 .112)(610.068)^{2}}$

$b=\frac{8.584 .957 .513 .200-8.582 .863 .671 .600}{372.370 .069 .344-372.182 .964 .624}$

$b=\frac{2.093 .841 .600}{187.104 .720}$

$b=11,19$

Sedangkan nilai a dapat ditentukan perhitungan berikut ini.

$a=\frac{\sum Y-b \sum X}{n}$

$a=\frac{14.068 .700-11,19(610.068)}{12}$

$a=\frac{14.068 .700 .000-6.826 .660,92}{12}$

$a=\operatorname{Rp} 603.503,256$.

Dengan demikian maka persamaan trend linier adalah :

$Y=603.503,256+11,19(X)$

Berdasarkan hasil perhitungan Regresi Volume Produksi dengan Biaya Reparasi dan Pemeliharaan Aktiva Tetap Bulan Januari s/d Desember Tahun 2014 maka diperoleh pemisahan biaya semi variabel ke dalam komponen dapat ditentukan dari biaya semi variabel sebesar Rp. 14.068.700,00 dipisahkan menjadi biaya tetap (a) sebesar $\mathrm{Rp} 7.242 .039,08$ dan biaya variabel (b) $\mathrm{Rp}$ 6.826.660,92 dengan melakukan pemisahan biaya semi variabel menjadi biaya tetap dan biaya variabel maka akan mempermudah penentuan contribution margin oleh perusahaan. Kalkulasi biaya produksi UD. Sinar Abadi tahun 2014 sebesar Rp $1.180 .549 .555,60$ dengan penjabaran jumlah biaya variabel $R p$ 1.138.053.775,92 dan biaya tetap $R p$ 42.495.779,68. Selanjutnya dalam penerapan incremental cost untuk memenuhi pesanan relugar,
UD.Sinar Abadi menetapkan harga jual normal yaitu Rp.4.500/kotak kue pia yang di dalam 1 kotak terdiri dari 10 potong kue pia. Dalam setiap bulannya UD.Sinar Abadi menerima pesanan khusus dari berbagai pelanggannya dan UD Sinar Abadi menetapkan harga jual untuk pesanan khusus $\mathrm{Rp} 3.750,00$. Namun menurut perusahaan apabila menerima pesanan khusus akan mengalami kerugian, hasil perhitungan perusahaan secara manual perusahaan mengalami kerugian total sebesar Rp. 7.527.000,00 per satu periode. Oleh karena itu peneliti menerapkan analisis incremental cost dalam pengambilan keputusan pesanan dapat dilihat pada Tabel 3.

\section{Tabel 3. Penerapan Incremental Cost dalam keputusan pengambilan pesanan}




\begin{tabular}{lccr}
\hline \multicolumn{1}{c}{ Keterangan } & $\begin{array}{c}\text { Penjualan Tanpa } \\
\text { Pesanan Khusus }\end{array}$ & $\begin{array}{c}\text { Penjualan Pesanan } \\
\text { Khusus }\end{array}$ & Total \\
\hline Produksi & 610.068 & 10.000 & 620.068 \\
\hline Penjualan & & & \\
$4.500 \times 610.068$ & $2.745 .306 .000,00$ & - & $2.782 .806 .000,00$ \\
$3.750 \times 10.000$ & - & $37.500 .000,00$ & \\
Total Biaya Variabel & $(1.183 .806 .450,60)$ & - & \\
$1.940,45 \times 610.068$ & - & $(19.404 .500,00)$ & $(1.203 .210 .950,60)$ \\
$1.940,45 \times 10.000$ & $1.561 .499 .549,40$ & $18.095 .500,00$ & $1.579 .595 .049,40$ \\
Batas Kontribusi & $(42.495 .779,68)$ & - & $(42.459 .779,00)$ \\
Total Biaya Tetap & - & $(1.230 .234,00)$ & $(1.230 .234,00)$ \\
Tambahan Biaya & $1.519 .003 .769,72$ & $16.865 .266,00$ & $1.535 .905 .036,40$ \\
\hline Laba Bersih & & & \\
\hline
\end{tabular}

Berdasarkan hasil perhitungan yang tampak pada tabel 3 penerapan incremental cost yaitu tambahan biaya sebesar Rp. 1.230.234,00 untuk membuat kue pia mampu menutup biaya variabel sebesar Rp.19.404.500,00 dengan menimbulkan contribution margin positif Rp.18.095.500,00 dan memberikan tambahan laba bagi perusahaan sebesar Rp.16.865.266,00.

\section{Pembahasan}

Berdasarkan hasil penelitian mengenai perhitungan pemisahan biaya semi variabel

sebesar Rp. 14.068.700,00 dipisahkan menjadi biaya tetap (a) sebesar $\mathrm{Rp}$ $7.242 .039,08$ dan biaya variabel (b)Rp 6.826.660,92 dengan melakukan pemisahan biaya semi variabel menjadi biaya tetap dan biaya variabel maka akan mempermudah penentuan contribution margin oleh perusahaan. Kalkulasi biaya produksi UD. Sinar Abadi tahun 2014 sebesar Rp 1.180.549.555,60. Melihat ketimpangan antara teori dengan pelaksanaan pengambilan keputusan oleh perusahaan. Dalam penelitian ini peneliti menerapkan salah satu analisis yang dapat digunakan dalam pengambilan keputusan pesanan yaitu analisis incremental cost, sesuai dengan kriteria penerimaan pesanan dengan penerapan incremental cost yaitu tambahan biaya sebesar Rp.
1.230.234,00 untuk membuat kulit kue pia mampu menutup biaya variabel sebesar Rp.19.404.500,00 dengan menimbulkan contribution margin positif sebesar Rp.18.095.500,00 dan memberikan tambahan laba bagi perusahaan sebesar Rp.16.865.266,00 sehingga pesanan khusus yang ditawarkan dapat diterima.Berdasarkan teori yang diungkapkan Mulyadi (2009: 153) pada umumnya manajemen menghadapi empat macam dalam pengambilan keputusan jangka pendek biaya diferensial salah satunya menerima atau menolak pesanan suatu produk. Dalam hal ini berdasarkan hasil yang diperoleh sejalan dengan teori yang melandasi, sama halnya dengan penelitian terdahulu (Andry, 2010) dimana perusahaan tersebut menerima pesanan khusus tersebut dengan pertimbangan akan memperoleh laba. Dalam penerimaan pesanan khusus menggunakan analisis incremental cost tidak diperlukan tambahan beban penjualan dan administratif, namun demikian diperlukan biaya tambahan untuk membeli tambahan bahan atau peralatan dalam memenuhi pesanan khusus tersebut. Dengan memperhatikan teori yang ada dan penelitian yang dilakukan maka analisis incremental cost ini dapat diterapkan pada masa yang akan datang, sehingga dapat

mengambil keputusan yang lebih baik dari sebelumnya.

\section{SIMPULAN DAN SARAN Simpulan}


Berdasarkan hasil penelitian maka dapat dibuat simpulan hal-hal sebagai berikut (1) pemisahan biaya semi variabel ke dalam komponen biaya tetap dan biaya variabel untuk penentuan contribution margin dalam pengambilan keputusan pesanan pada UD. Sinar Abadi Singaraja tahun 2014 dapat ditentukan dari besarnya biaya semi variabel sebesar Rp. 14.068.700,00 dipisahkan menjadi biaya tetap (a) sebesar $\mathrm{Rp}$ 7.242.039,08 dan biaya variabel (b) $R p$ 6.826.660,92 dengan melakukan pemisahan biaya semi variabel menjadi biaya tetap dan biaya variabel maka akan mempermudah penentuan contribution margin oleh perusahaan. Kalkulasi biaya produksi UD. Sinar Abadi tahun 2014 sebesar Rp 1.180.549.555,60. (2) penerapan incremental cost dalam pengambilan keputusan pesanan pada UD.Sinar Abadi tahun 2014 setelah dilakukan perhitungan dan dipadukan dengan kriteria penerimaan pesanan menyatakan penerapan incremental cost yaitu tambahan biaya sebesar Rp. 1.230.234,00 untuk membuat kue pia mampu menutup biaya variabel sebesar Rp.19.404.500,00 dengan menimbulkan contribution margin positif Rp.18.095.500,00 dan memberikan tambahan laba bagi perusahaan sebesar Rp.16.865.266,00 maka dengan memperhatikan hal tersebut pesanan khusus dapat diterima. Apabila pesanan khusus tersebut menyebabkan kerugian bagi perusahaan maka pesanan khusus dapat ditolak. Hal ini menunjukkan bahwa masih memungkinkan bagi perusahaan untuk menerima pesanan khusus lain dengan pertimbangan yang sama untuk memperoleh tambahan laba. Dengan demikian analisis seperti ini dapat diterapkan pada masa yang akan datang, sehingga dapat mengambil keputusan yang lebih baik dari sebelumnya.

\section{Saran}

Berdasarkan hasil penelitian dan pembahasan yang telah dijabarkan serta kesimpulan yang telah diuraikan sebelumnya, maka saran yang dapat dikemukakan sebagai berikut.

Bagi UD. Sinar Abad, penggunaan analisis incremental cost alangkah baiknya dapat diterapkan sehingga dalam menerima pesanan dalam jumlah banyak dapat digunakan untuk menganalisis sehingga mendapatkan jumlah laba yang optimal. Dalam penerimaan pesanan khusus yang ditawarkan dengan adanya analisis ini diharapkan perusahaan untuk menerima pesanan khusus tersebut.

Bagi peneliti lain yang akan melakukan penelitian tentang biaya tambahan diharapkan mampu menganalisis dengan metode analisis yang lain dan lebih rinci sehingga penggolongan biaya-biaya yang dikeluarkan dapat dispesifikasikan lagi. Selain itu, bagi peneliti berikutnya mampu menambahkan variabel dan data yang lebih mendukung penelitian selanjutnya sehingga hasil yang didapatkan lebih optimal.

\section{DAFTAR PUSTAKA}

Adolph Matz, dkk. 2000. Akuntansi Biaya Perencanaan dan Pengendalian Jilid 2. Jakarta: Erlangga.

Ahmad Dunia, Firdaus.2012.Akuntansi Biaya.Edisi ketiga.Jakarta:Salemba Empat.

Ahmad Kamaruddin.2007.Akuntansi Manajemen "Dasar-Dasar Konsep Biaya dan Pengambilan Keputusan,edisi kelima.Jakarta:Raja Grafindo Persada.

Andry.2011.Analisis penerapan biaya relevan dalam menerima atau menolak pesanan khusus pada PT.Adinata Makasar.Skripsi Fakultas Ekonomi dan Bisnis Universitas Hasanudin.Makasar.

Bungin, Burhan.2009.Metodelogi penelitian kuantitatif. Jakarta: Kencana Prenada Media Group. 
Bustami

Bastian,

dan

Nurlela.2009.Akuntansi Biaya

"Melalui

Pendekatan

Manajerial.edisi

pertama.Jakarta:Mitra Wacana

Media.

Carter,W.K

dan

Usry,M.F.2009.Akuntansi

Biaya(Cost

Accounting)

diterjemahkan Oleh Krista,

Jakarta:Salemba Empat.

Hansen dan Mowen.2009.Manajemen Biaya Akuntansi dan

Pengendalian,edisi ketujuh buku 2.Jakarta:Salemba Empat.

Harahap,Sofyan.2005. Teori

Akuntansi,Jakarta:Raja Grafindo.

Hariadi, Bambang, 2002, Akuntansi Manajemen Suatu Sudut Pandang, edisi pertama, cetakan pertama, Penerbit: BPFE, Yogyakarta.

Maher Michael, dan Edward B. Deakin. 2006. Akuntansi Biaya Edisi Empat. Jakarta:Erlangga.

Munawir, S, 2002, Akuntansi Keuangan dan Manajemen, edisi pertama, cetakan pertama, Penerbit : BPFE, Yogyakarta.

\author{
Mulyadi.2009.Akuntansi Biaya.edisi \\ kelima.cetakan \\ kesembilan.Yogyakarta:UPP \\ STIM YKPN.
}

Santosa, Darius. 2003. Peranan Analisis Biaya Defferensial Dalam Pengambilan Keputusan Keputusan Memproduksi Sendiri atau Membeli produk Garmen Guna Meningkatkan Laba (studi kasus Pada PT X): Bandung: Skripsi fakultas Ekonomi Universitas Widyatama.

Sugiri,Selamet.2009.Akuntansi Manajemen.edisikedua.Yogyakart a: UPP AMP YKPN.
Sugiyono.2012.Metode Penelitian kuantitatif, kualitatif dan $R \& D$. Bandung:Alfabeta.

Supriyono,R.A.2005.Akuntansi Biaya "Pengumpulan Biaya dan Penentuan Harga Pokok.edisi kedua.Yogyakarta:BPPE.

Supriyono,R.A.2005. Akuntansi Biaya dan Akuntansi Manajemen untuk Teknologi Maju dan Globalisasi. Yogyakarta: BPFE - Yoyakarta.

Witjaksono,Armanto.2013.Akuntansi Biaya.edisi pertama cetakan pertama. Yogyakarta:Graha 